Geosci. Model Dev. Discuss., https://doi.org/10.5194/gmd-2018-5

Manuscript under review for journal Geosci. Model Dev.

Discussion started: 14 March 2018

(c) Author(s) 2018. CC BY 4.0 License.

\title{
A new tool for model assessment in the frequency domain - Spectral Taylor Diagram : application to a global ocean general circulation model with tides
}

CALIM, Mabel Costa ${ }^{1, *}$; NOBRE, Paulo ${ }^{1}$; OKE, Peter ${ }^{2}$; SCHILLER, Andreas²; SIQUEIRA, Leo San Pedro ${ }^{3}$; CASTELÃO, Guilherme Pimenta ${ }^{4}$

${ }^{1}$ National Institute for Space Research, Cachoeira Paulista, SP 16300-000, Brazil

${ }^{2}$ CSIRO -Oceans and Atmosphere, Centre for Australian Weather and Climate Research, G.P.O. Box 1538, Hobart TAS 7001, Australia

${ }^{3}$ Rosenstiel School of Marine and Atmospheric Science, University of Miami, 4600 Rickenbacker Causeway, Miami, FL 33149-1098, USA

${ }^{4}$ Scripps Institution of Oceanography 9500 Gilman Drive, La Jolla, California 92093

Corresponding Author: mabelcalim@gmail.com

\section{Abstract}

We introduce a new tool - the Spectral Taylor Diagram (STD) - for the comparison of time series in the frequency domain. The STD provides a novel way of displaying the squared-coherence, power, amplitude, phase, and root-mean-squared difference of discrete frequencies of two time-series. Each STD summarises these quantities in a single plot, for multiple targeted frequencies. The versatility of STDs is demonstrated through a series of sea-level comparisons between observations from tide gauges, and model results from a global eddy-permitting ocean general circulation model with explicit tidal forcing.

Keywords: Model evaluation; Spectral Taylor Diagrams; Ocean tides; global ocean modelling

Highlights:

- A new tool to evaluate tides is introduced: Spectral Taylor Diagram

- Ocean General Circulation model with explicit tidal forcing. 
Geosci. Model Dev. Discuss., https://doi.org/10.5194/gmd-2018-5

Manuscript under review for journal Geosci. Model Dev.

Discussion started: 14 March 2018

(c) Author(s) 2018. CC BY 4.0 License.

Ocean and climate modelling are widely used for research, forecasting, and climate projections. An important step in the application of an ocean or climate model is model assessment. This is commonly done by comparing model results to observations and reanalysis (Landerer and Glecker, 2014, Chiyuan Miao et al 2014), or to other models (Flato et al., 2013). Such comparisons often involve single variable to multi-variables, multi-processes, and multi-phenomena employing methods of mathematical statistics for quantitative evaluations as well as parametric or nonparametric tests of significance. Traditional statistical comparisons in the time-domain typically include calculation of correlations, and comparison of standard deviations, means, and trends (e.g., Schiller and Brassington, 2011). Second order comparisons often compare some variant of empirical orthogonal functions (e.g., Erofeeva et al., 2003). Comparisons in the frequency domain typically involve considerations of the cross-spectral density, squared-coherence, phase, and amplitude at a range of frequencies. In cases where a specific frequency band is targeted to isolate a particular process, for example - analysis techniques such as wavelets, or complex demodulation are commonly employed (Flinchem and Jay, 2000). Each type of comparison has strengths and weaknesses. A challenge for any model assessment is the concise depiction of multiple statistical metrics for easy interpretation. Taylor Diagrams (TDs; Taylor, 2001) are now commonly used to concisely present multiple statistical properties from the comparison in the time-domain. In this paper, we introduce a tool that is analogous to TDs but for spectral comparisons - the Spectral Taylor Diagram (STD).

We demonstrate the versatility of STDs through a series of assessments of a global, eddy-permitting ocean general circulation model with explicit tidal forcing. To date, most global ocean models and climate models do not include explicit tidal forcing - with a few notable exceptions (Schiller 2004; Schiller and Fiedler 2007; Arbic et al.,2012; Müller et al., 2012; and Ngdock et al. 2016) - largely because of the understanding that tidal energy is completely dissipated in shallow waters (Wunsch 2000). However, many observations of tides indicate that tides might be more important than previously thought. For example, Lee et al. (2006) shows that barotropic tidal energy in coastal regions is several orders of magnitude greater than the deep ocean. Moreover, Munk and Wunsch (1998) concluded that mixing driven primarily by dissipation of tidal energy could contribute to one half of the power required to return the deep waters to the surface.

The accuracy of ocean models, forced with tides, remains limited by uncertainties in a range of model parameters (Schiller 2004; Schiller and Fiedler 2007; and Ngodock et al. 2016), such as inaccurate bathymetry, bottom friction, model resolution, inaccurate estimation of 
Geosci. Model Dev. Discuss., https://doi.org/10.5194/gmd-2018-5

Manuscript under review for journal Geosci. Model Dev.

Discussion started: 14 March 2018

(c) Author(s) 2018. CC BY 4.0 License.

internal tides, and misrepresentation of the self-attraction and loading term (SAL). Another important source of barotropic errors in ocean modelling is introduced by an inaccurate estimation of phase information. In this study, we compare results from two model configurations with tides, to observations. We use version 5 of the Modular Ocean Model (MOM5) with it's default tidal configuration (DFT) and with the addition of phase information (T8).

This paper is organised as follows. The STDs are described in section 2, the model is described in section 3, and applications of STDs are presented in section 4 . We conclude and summarise our findings in section 5 .

\section{Spectral Taylor Diagrams - STDs}

Taylor Diagrams (TDs; Taylor 2001) are often used to intercompare results from different models with observations (e.g., Oke et al. 2012). TDs (e.g., Figure 1) represent unbiased Root-Mean-Squared Error (RMSE; i.e., RMSE with the mean removed), the cross-correlation between observed and modelled estimates, and the standard deviation of the analysed time-series. Some presentations of TDs also include a metric of skill-score (e.g., Divikan et al. 2012). These diagrams nicely summarise a number of statistical comparisons in a single plot. TDs exploit the relationship between three statistical quantities that compose the law of cosines. The correlation coefficient $(R)$, the standard deviations of the test $\left(\sigma_{f}\right)$ and reference $\left(\sigma_{r}\right)$ fields, and the centered root-mean-square difference $\left(E^{\prime}\right)$ between these two fields create a two-dimensional diagram through the following formula:

$E^{\prime 2}=\sigma_{f}^{2}+\sigma_{r}^{2}-2 \sigma_{f} \sigma_{r} R$

which resembles the law of cosines,

$c^{2}=a^{2}+b^{2}-2 a b \cos \varphi$.

This geometric relationship is represented graphically in Figure 2.

In this paper, we introduce a new tool for inter-comparing different time-series against observations, based on a variant of TDs that we call STDs. Instead of calculating the correlation of an entire time-series with the observation, we select a frequency (or a band of frequencies) to be assessed. Here, a transformation is used to convert the time domain signal to the frequency domain. Furthermore, the choice of the three statistical quantities has to satisfy the law of cosines, such that the correlation is replaced by spectral coherence, and the standard deviation of the power replaces the time series standard deviation. 
Geosci. Model Dev. Discuss., https://doi.org/10.5194/gmd-2018-5

Manuscript under review for journal Geosci. Model Dev.

Discussion started: 14 March 2018

(c) Author(s) 2018. CC BY 4.0 License.

The squared-coherence is analogous to time domain measure of correlation, and is employed here since it also measures the strength of the linear relationship between two time series - ranging from 0 to 1 (the first quadrant of the diagram). Two time-series are considered highly coherent for a given frequency if the squared-coherency is close to 1 and the phase is close to 0 (Emery and Thomson, 2001). This is represented by

$\gamma_{12}^{2}\left(f_{k}\right)=\left|G_{12}\left(f_{k}\right)^{2}\right| / G_{11}\left(f_{k}\right) G_{22}\left(f_{k}\right)$,

where $\gamma_{12}{ }^{2}\left(f_{k}\right)$ is the squared-coherency, $G_{11}\left(f_{k}\right)$ the one-sided Fourier spectrum of the first time-series for all frequencies $\left(f_{k}, k=0,1, \ldots N-1\right), G_{22}\left(f_{k}\right)$ is the one-sided Fourier spectrum of the second time-series, and $G_{12}\left(f_{k}\right)$ is the cross-spectrum between the first and the second time-series (Emery and Thomson, 2001).

The standard deviation of the power measures the amplitude of the signals while the centered RMS difference provides information about the centered pattern error, derived from the geometric relationship. The signals should combine higher coherence with enough energy to be considered co-oscillating.

The STD is like the TD, where the radial distances provide the standard deviations of the power, the azimuthal position gives the squared-coherence, and the concentric labeled lines indicate the centered RMS difference. The radial lines represent the cosine of the angle made with the abscissa thus consistent with Figure 2. The reference point (usually the observation data), marked with a black dot or star, is placed on the x-axis, whereas it's the one with the maximum coherence. The test data (e.g., the model's simulations) are assessed for the ability to represent the reference data.

Although the mathematical relationship applies to two quadrants of the STD, as in the TD, the STD is only meaningful in the first quadrant; since a negative coherence is not applicable. The best performance is given by the test with lowest centered RMS difference, higher coherence, and similar energy.

Figure 3 shows an example of an STD for artificial time series where there is a difference in the amplitude and phase of the "model" results that are being inter-compared with "observations". The frequency in this case is fixed, but it is also possible to consider frequency bands. The tests are normalized by the reference standard deviation of the power. The amplitude changes are proportional to radial distances, except in the case where the test amplitude is a multiple of the reference amplitude, where the pattern described is horizontal and exactly positioned along the abscissa axis. An increase in amplitude by multiple values is expressed in the diagram as multiples of the standard deviation of the 
Geosci. Model Dev. Discuss., https://doi.org/10.5194/gmd-2018-5

Manuscript under review for journal Geosci. Model Dev.

Discussion started: 14 March 2018

(c) Author(s) 2018. CC BY 4.0 License.

normalized power. The coherence, in this case, is equal to 1 , but horizontally shifted showing the amplification of the signal. For example, varying the amplitude by one third (solid blue line) or reducing by two thirds (dashed blue line), the coherence is reduced to 0.98 and 0.91 , the centered RMS difference increases to 0.80 and 0.90 , while the normalized standard deviation is extended to 1.77 and 0.11 , respectively.

The coherence is highly dependent on the phase. Therefore, keeping the amplitude unchanged and only varying the phase values from one quarter (dashed red line) to plus one half (red line), the normalized standard deviation stays fixed, at 1 , while the coherence is reduced from 0.76 to 0.27 , and the centered RMS difference increases from 0.69 to 1.21 .

The power spectrum shown in Figure 3D does not clearly demonstrate the contrast when varying the amplitude and phase of the time series. The STD displays both coherence and power, therefore, highlighting the co-oscillating frequencies overcoming the limited information contained in a power spectrum analysis. The need for better representing the degree of correspondence between simulated and observed fields for a given frequency (or frequency bands) is fulfilled by this novel tool inspired by relevant tide features.

\section{Model Description}

MOM5 (Griffies et al. 2012) is a hydrostatic (z-model), primitive equation model with free surface. The model configuration used here has a global grid of $1 / 4^{\circ} \times 1 / 4^{\circ}$ horizontal resolution, comprised of $720 \times 1400$ grid points and with 50 vertical levels. The first vertical level is $10 \mathrm{~m}$ from the surface and vertical resolution of $10 \mathrm{~m}$ down to $220 \mathrm{~m}$. Below this depth, the levels are discretized by $166 \mathrm{~m}$ to the bottom. This horizontal resolution is eddy-permitting and permits representation of barotropic tides. However, the model resolution is insufficient to resolve internal tides. Here, we focus on the explicit barotropic tidal forcing and its relevance for the contemporary HighResMIP for CMIP6 (Coupled Model Intercomparison Project 6) experiments that use global climate models with a similar $1 / 4^{\circ} \times 1 / 4^{\circ}$ resolution for ocean models (Haarsma et al., 2016).

The model topography is derived from ETOPO5 ${ }^{1}$; the Boussinesq approximation is employed, and the vertical grid uses a $z^{*}$ coordinate. The surface fields are extracted from the Coordinated Ocean-ice Reference Experiments (CORE1) using climatological forcing for temperature and salinity from Levitus and Boyer (1994). Surface heat fluxes, precipitation, wind stress, and river fluxes are from CORE1. Surface salinity is restored to monthly averaged climatology with a timescale of 60 days. The vertical viscosity and diffusivity are parameterized by the KPP scheme, updated from MOM4.0 to MOM4p1 to resolve the free

${ }^{1}$ http://www.ngdc.noaa.gov/mgg/global/global.html 
Geosci. Model Dev. Discuss., https://doi.org/10.5194/gmd-2018-5

Manuscript under review for journal Geosci. Model Dev.

Discussion started: 14 March 2018

(c) Author(s) 2018. CC BY 4.0 License.

surface undulation. Bryan-Lewis background diffusivity is turned off to prepare the model to use the barotropic dissipation from Lee et al. (2006) and baroclinic dissipation from Simmons et al. (2004) for future studies.

Three individual 20 years tidal simulations are run, which is sufficient to span the nodal tide period of 18.6 years. Each 20-year simulation is initialised from the final state of a 60-year spinup. We consider the spinup period to be sufficiently long for an evaluation of the upper ocean. The three experiments performed include: a control run without the tidal potential, hereafter referred to as CNTRL; a run equivalent to CNTRL, but with explicit tidal forcing using the eight principal lunisolar constituents (M2, S2, N2, K2, K1, O1, P1, Q1 without phase information, hereafter referred to as DFT (this if the default configuration of MOM5); and a run equivalent to DFT, but with phase information and amplitude adopted from OSU Tidal Inversion Software ${ }^{2}$, hereafter referred to as T8.

The sea elevation adjustment is virtually instantaneous assuming the ocean is always in equilibrium with tidal forces and disregarding the Darwin's correction when estimating the equilibrium tide height in the presence of continents (Marchuk and Kagan, 1989). Observations show that it is possible to simulate and predict the actual tide from equilibrium form considering that it has been delayed and distorted slightly by the process of generation and propagation (Schiller, 2004). The equilibrium tide in MOM5 is described considering the tide-generating potential with corrections due to both the earth tide self-attraction and loading (SAL). A scalar approximation to $S A L$ is assumed to be equal to 0.948. The equilibrium of tides described as a sum of harmonics, mainly diurnal and semidiurnal constituents, is integrated into the momentum budget of the Boussinesq approximation added to the transport equation, as shown in details in Griffies et al. (2004).

The tidal amplitude and phase adopted in the T8 experiment are based on astronomical arguments used by OSU Tidal Prediction Software with initial condition dated 1st January 1992 00:00 Greenwich time, shown in Table 1. No update is made to the astronomical argument of the partial tide that is known slightly time-dependent (Schwiderski, 1980).

\section{Application of STDs}

As described in section 2, the traditional approach to model assessment is to compare individual statistics separately. An example of such an assessment is presented in Figure 4. This figure depicts the averaged amplitude of the semidiurnal (yellow) and diurnal (green) tides for 29 tide gauge stations around the world. This includes estimates at the end of the $10^{\text {th }}$ (coloured circle) and $20^{\text {th }}$ (black circle) year of the DFT and T8 runs; and estimates from

${ }^{2}$ http://volkov.oce.orst.edu/tides/otis.html 
Geosci. Model Dev. Discuss., https://doi.org/10.5194/gmd-2018-5

Manuscript under review for journal Geosci. Model Dev.

Discussion started: 14 March 2018

(c) Author(s) 2018. CC BY 4.0 License.

observations (grey circle). This comparison shows a mix of results. In some cases, the modelled and observed tidal amplitudes are similar (e.g., across the Pacific Ocean), while other cases there are large discrepancies between the modelled and observed tidal amplitudes (e.g., off North-Western Australia). These results are only one element of the comparisons needed to assess the model's reproduction of the tidal signals. Arguably, a better way of assessing the model's reproduction of the observed tidal signals is presented in Figure 5. The values in each STD are normalized by the reference standard deviation of power, enabling the inter-comparison of the change in model performance over different periods of the simulation.

In the Atlantic, the T8 experiment shows a noticeable improvement for diurnal constituents (Fig.5A) at the selected Ilha Fiscal tide gauge, which is not evident in Figure 4. The coherence increased from 0.59 to 0.72 and the centered RMS error reduced from 1.03 to 0.95. However, T8 overestimates the energy content from 1.22 to 1.36 . DFT has a better response for semidiurnal constituents (coherence increases from 0.66 to 0.73 ) while T8 keeps almost unchanged. At the Gan tide gauge station it is also difficult to differentiate between the experiments in Figure 4, but it is well stated in Figure 5B that T8 improves both semidiurnal and diurnal constituents. For both experiments, all tidal constituents are underestimated at the Gan tide gauge station. In the Pacific, at Townsville tide gauge station, T8 has improved the coherence for semidiurnal from 0.56 to 0.68 and for diurnal constituents from 0.54 to 0.72 . However, DFT has a better estimate for diurnal constituents, reducing the centered RMS error from 0.82 to 0.65 , enhancing the coherence from 0.59 to 0.76 , and increased power from 0.69 to 0.83 as shown in Figure $5 \mathrm{C}$. The semidiurnal constituents started with higher coherence in DFT (Figure 5C) in agreement with Figure 4, but decreased throughout the run. The higher coherence shown by the semidiurnal constituents for the vast majority of tide gauges is due to a severe underestimation of power and therefore amplitude in the model's simulations.

A comprehensive assessment of the model for all stations focusing on one frequency and a single (Figure 6) or multiple bands of frequencies (Figure 7) is only possible by using STD. A selection of the 17 tidal stations with significant data for evaluate long term frequencies is done for Figure 6 and 7. It's possible to certify that the model superestimates semidiurnal and diurnal bands in the Bering Sea (tide station number 12) while underestimates long term and semidiurnal bands for most of tide stations. As expected, M2 is also underestimated in the model expect for region close to north-eastern coast of Queensland (tide station number $6)$. 
Geosci. Model Dev. Discuss., https://doi.org/10.5194/gmd-2018-5

Manuscript under review for journal Geosci. Model Dev.

Discussion started: 14 March 2018

(c) Author(s) 2018. CC BY 4.0 License.

Separated in basins style, Figure 7 shows that is possible to evaluate multiple bands in multiple regions. The model has better response to diurnal band, than in other frequencies. In the Atlantic, the better response was shown close to Palmeira, Halifax and Ilha Fiscal tide stations, as shown in Figure 7. The best response of diurnal band it placed in the Indian Ocean, where the best fit is shown in Gan tide station (shown in APPENDIX A). Australia diurnal band is well represented by the model in both Indian and Pacific Oceans. The M2, semidiurnal and long-term bands are underestimated in the model except for regions close to Townsville (better response for M2) and Fremantle (overestimated semidiurnal band) (shown in APPENDIX A).

\section{Conclusions and Further applications}

A new tool designed to help in the assessment and inter-comparison of model results in the frequency domain is presented. The STD arguably provide a better summary of each comparison - better highlighting the positive and negative aspects of each comparison. STDs may benefit other studies that seek to assess models - or inter-compare models - for specific frequencies, or for specific frequency bands, that might correspond to a particular process of interest. For the examples used to showcase this new analysis tool in this study, we showed a series of comparisons between a global model with explicit tidal forcing.

In contrast to Taylor Diagram, the spectral version enables a multiple band of frequencies preview without using filtering techniques. Multi regions comparison it's also possible using a normalized standard deviation of power strategy, that can be also useful to track model's skills over different periods of the simulation. The versatility of STD is based on detection of anomalous patterns in a phenomena analysis.

Although the STD has been designed for tidal analysis purpose, it is a powerful tool to detect co-oscillating patterns in multi scale analysis, and may provide a guidance in devising skill scores for inter-compare models.

\section{Code and data availability}

Spectral Taylor Diagram is an open source script available at https://github.com/mabelcalim, as well as the figures plots created with IPython Notebook. The harmonic analysis based on pytides (available in https://github.com/sam-cox/pytides), an open source script in python made by Sam Cox, was parallelized in the Brazilian Supercomputer Tupã. 
Geosci. Model Dev. Discuss., https://doi.org/10.5194/gmd-2018-5

Manuscript under review for journal Geosci. Model Dev.

Discussion started: 14 March 2018

(c) Author(s) 2018. CC BY 4.0 License.

Funding: This work was supported by National Counsel of Technological and Scientific Development (CNPQ), Grants No. 2012/02675-21, Coordination for the Improvement of Higher Education Personnel (CAPES) Grant No. 99999.005769/2014-00 (Migrado - BEX) (Doutorado-Sanduiche Australia), Bolsa Projeto CAPES/ANA BESM Grant No. 88887.115872/2015-01, and the National Institute for Science and Technology for Climate Change - INCT-MC Grant No. 465501/2014-1.

Acknowledgments. We thank Russell Fiedler (CSIRO), Manoel Baptista da Silva Junior (INPE/CPTEC), and Vanderlei Marques Pereira (INPE/CPTEC/CRAY) for their support and assistance. The model simulations were performed on INPE's Supercomputer CRAY EX6 in Cachoeira Paulista. This study is part of the Brazilian Earth System Model (BESM) project and was funded by the National Counsel of Technological and Scientific Development (CNPQ) and the Coordination for the Improvement of Higher Education Personnel (CAPES). This paper it is a result of Brazilian investment in science promoting international collaborations by engaging students in highly qualified academic or research centers around the globe - Science without Borders funding. We also thanks CSIRO for the partnership on this project.

\section{References}

Arbic, B.K., Richman, J.G., Shriver, J.F., Timko,P.G.,Metzger, E.J.,Wallcraft, A.J., 2012: Global modelling of internal tides within an eddying ocean general circulation model, Oceanography, 25, 20-29, doi:10.5670/oceanog.2012.38.

Chiyuan Miao, Qingyun Duan, Qiaohong Sun, Yong Huang, Dongxian Kong, Tiantian Yang, Aizhong Ye, Zhenhua Di and Wei Gong, 2014:Assesment of CMPI5 climate models and projected temperature changes over Northern Eurasia. Environmental Research Letters, 9,055007.

Divakaran, P., Brassington, G. $\quad$ B, Ryan, A. G., Regnier, C., Spindler, T., Mehra, A., Hernandez, F., Smith, G. C., Liu, Y., and Davidson, F.: GODAE OceanView Inter-comparison for the Australian Region, J. Op. Oceanogr., 8, s112-s126, 2015.

Emery, W. J.; Thomson, R. E.,2001. Data analysis methods in Physical Oceanography. Amsterdam: Elsevier Science BV, 2001. 636p. ISBN 0-444-50757-4. 
Geosci. Model Dev. Discuss., https://doi.org/10.5194/gmd-2018-5

Manuscript under review for journal Geosci. Model Dev.

Discussion started: 14 March 2018

(c) Author(s) 2018. CC BY 4.0 License.

Erofeeva, S.Y., G.d. Egbert, and P.M. Kosro, 2003: Tidal currents on the central Oregon shelf: Models, data and assimilation, J. Geophys. Res., 108(C5), 3148, doi:10.1029/2002JC001615.

Flato, G., J. Marotzke, B. Abiodun, P. Braconnot, S.C. Chou, W. Collins, P. Cox, F. Driouech, S. Emori, V. Eyring, C. Forest, P. Gleckler, E. Guilyardi, C. Jakob, V. Kattsov, C. Reason and M. Rummukainen, 2013: Evaluation of Climate Models. In: Climate Change 2013: The Physical Science Basis. Contribution of Working Group I to the Fifth Assessment Report of the Intergovernmental Panel on Climate Change [Stocker, T.F., D. Qin, G.-K. Plattner, M. Tignor,S.K. Allen, J. Boschung, A. Nauels, Y. Xia, V. Bex and P.M. Midgley (eds.)]. Cambridge University Press, Cambridge,United Kingdom and New York, NY, USA.

Flinchem, E.P., and D.A. Jay, 2000: An Introduction to Wavelet Transform Tidal Analysis Methods. Estuarine, Coastal and Shelf Science, 51, 177-200, doi:10.1006/ecss.2000.0586.

Griffies,S.M., 2004. Fundamental of Ocean Climate Models, 518 pp., Princeton Univ. Press, Princeton, N.J.

Griffies, S.M., 2012. Elements of the Modular Ocean Model (MOM) (2012 release). GFDL Ocean Group Report n.7, p 618.

Haarsma, R.J., Roberts, M.J., Vidale, P.L.,Senior, C.A.,Bellucci, A.,Bao,Q., Chang,P., Corti,S., Fuckar,N.S., Guemas,V., Hardenberg,J.V., Hazeleger,W., Kodama,C., Koenigk, T., Leung,L.R., Lu,J., Luo,J., Mao,J., Mizielinski,M.S., Mizuta, R., Nobre, P., Satoh, M., Scoccimarro, E., Semmler, T., Small, J., Storch, J.,2016: High Resolution Model Intercomparison Project (HighResMIP v1.0) for CMIP6. Geosci. Model Dev., 9, 4185-4208. doi:10.5.194/gmd-9-4185-2016.

Lee, H., Rosati,A.,Spelman, M.J., 2006: Barotropic tidal mixing effects in a coupled climate model: Oceanic conditions in the Northern Atlantic. Ocean Modell.,11, 464-477.

Levitus, S., Boyer, T., 1994. World Ocean Atlas 1994, Vol. 4: Temperature.NOAA Atlas NESDIS 4, U.S. Gov. Printing Office, Wash., D.C.,117p.

Marchuk, G.; and B., Kagan, 1989: Dynamics of Ocean Tides. [S.I.]: Kluwer Academic.

Müller,M.,Cherniawsky, J.Y.,Foreman,M.G.G., von Storch, J.S., 2012. Global map of M2 internal tide and its seasonal variability from high resolution ocean circulation and tide modeling, Geophys. Res. Lett., 39, L19607, doi:10.1029/2012GL053320.

Munk, W., and Wunsch, C., 1998: Abyssal recipes II: energetics of tidal and wind mixing. Deep-Sea Research I, 45, 1977-2010. 
Geosci. Model Dev. Discuss., https://doi.org/10.5194/gmd-2018-5

Manuscript under review for journal Geosci. Model Dev.

Discussion started: 14 March 2018

(c) Author(s) 2018. CC BY 4.0 License.

Ngodock, H.E., Souopgui, I., Wallcraft, A. J., Richman, J. G., Shriver, J. F., Arbic, B. K. 2016: On improving the accuracy of the M2 barotropic tides embedded in a high-resolution global ocean circulation model. Ocean Modell., 97, 16-26.

Oke, P. R., G. B. Brassington, J. Cummings, M. Martin, F. Hernandez, 2012: GODAE Inter-comparisons in the Tasman and Coral Seas, Journal of Operational Oceanography, 5, 11-24.

Schiller, A. 2004: Effects of explicit tidal forcing in an OGCM on the water-mass structure and circulation in the Indonesian throughflow region. Ocean Modell., 6, 31-49.

Schiller, A. and Fieldler, R., 2007: Explicit tidal forcing in an ocean general circulation model, Geophys. Res. Lett., 34, L03611, http://dx.doi.org/10.1029/2006/GL028363.

Schiller, A., Brassington, G.B., 2011: Operational oceanography in the 21st century. Springer, Dordrecht, $745 \mathrm{pp}$.

Schwiderski, E.W., 1980. On Charting Global Ocean Tides, Reviews of Geophysics and Space Physics, 19, 1, 243-268.

Simmons, H. L., Jayne, S.R., St.Laurent, L., Weaver, A.J., 2004. Tidally driven mixing in a numerical model of ocean general circulation, Ocean Modell.,6, 245-263.

Taylor, K.E.,2001. Summarizing multiple aspects of model performance in a single diagram.J. Geophys. Res., 106, D7, 7183-7192.

Wunsh, C., 2000. Moon, tides and climate. Nature, 405, 743-744. doi:10.1038/35015639. 
Geosci. Model Dev. Discuss., https://doi.org/10.5194/gmd-2018-5

Manuscript under review for journal Geosci. Model Dev.

Discussion started: 14 March 2018

(c) Author(s) 2018. CC BY 4.0 License.

Table 1: Global constants of tidal frequency, amplitude, and phase applied for experiments

DFT and T8. Love numbers are frequency dependent and generally close to 0.7.

\begin{tabular}{|c|c|c|c|c|c|c|}
\hline & \multirow{2}{*}{ Tidal Mode } & \multirow{2}{*}{ frequency $(\mathrm{Hz})$} & \multirow{2}{*}{ Love numbers } & DFT & \multicolumn{2}{|r|}{ T8 } \\
\hline & & & & $\begin{array}{c}\text { amplitude } \\
\text { (m) }\end{array}$ & $\begin{array}{c}\text { amplitude } \\
\text { (m) }\end{array}$ & $\begin{array}{c}\text { Phase } \\
\text { (rad) }\end{array}$ \\
\hline \multicolumn{7}{|c|}{ semidiurnal } \\
\hline M2 & $\begin{array}{l}\text { principal } \\
\text { lunar }\end{array}$ & $1.4051910^{4}$ & 0.693 & 0.242334 & 0.244102 & 1.731557546 \\
\hline $\mathrm{S} 2$ & $\begin{array}{l}\text { principal } \\
\text { solar }\end{array}$ & $1.4544410^{4}$ & 0.693 & 0.112743 & 0.113568 & 0.000000000 \\
\hline N2 & $\begin{array}{l}\text { elliptical } \\
\text { lunar }\end{array}$ & $1.3788010^{4}$ & 0.693 & 0.046397 & 0.046735 & 6.050721243 \\
\hline K2 & $\begin{array}{l}\text { declination } \\
\text { Iuni-solar }\end{array}$ & $1.4584210^{4}$ & 0.693 & 0.030684 & 0.030879 & 3.487600001 \\
\hline \multicolumn{7}{|c|}{ diurnal } \\
\hline $\mathrm{K} 1$ & $\begin{array}{l}\text { declination } \\
\text { Iuni-solar }\end{array}$ & $0.7292110^{4}$ & $1.0+0.256-0.520$ & 0.141565 & 0.142435 & 0.173003674 \\
\hline $\mathrm{O} 1$ & $\begin{array}{l}\text { principal } \\
\text { lunar }\end{array}$ & $0.6759810^{4}$ & $1.0+0.298-0.603$ & 0.100661 & 0.101270 & 1.558553872 \\
\hline P1 & $\begin{array}{l}\text { principal } \\
\text { solar }\end{array}$ & $0.7252310^{4}$ & $1.0+0.287-0.603$ & 0.046848 & 0.047129 & 6.110181633 \\
\hline Q1 & $\begin{array}{l}\text { elliptical } \\
\text { lunar }\end{array}$ & $0.6495910^{4}$ & $1.0+0.298-0.603$ & 0.019273 & 0.019387 & 5.877717569 \\
\hline
\end{tabular}


Geosci. Model Dev. Discuss., https://doi.org/10.5194/gmd-2018-5 Manuscript under review for journal Geosci. Model Dev.

Discussion started: 14 March 2018

(c) Author(s) 2018. CC BY 4.0 License.
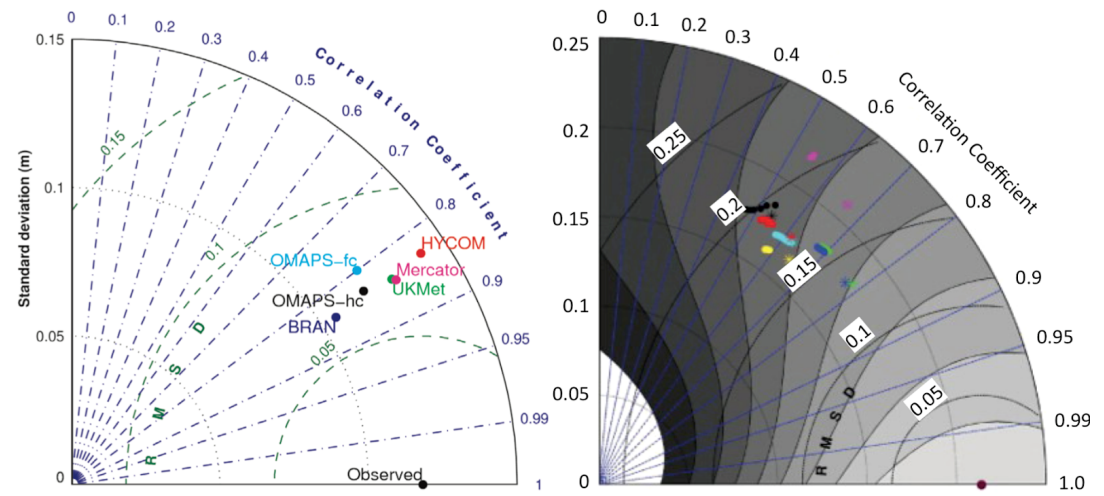

418

Figure 1: Example of a standard Taylor Diagram (left; adapted from Oke et al. 2012); and a

419

Taylor Diagram with a skill-score (right; adapted from Divakaran et al. 2012). 
Geosci. Model Dev. Discuss., https://doi.org/10.5194/gmd-2018-5 Manuscript under review for journal Geosci. Model Dev.

Discussion started: 14 March 2018

(c) Author(s) 2018. CC BY 4.0 License.
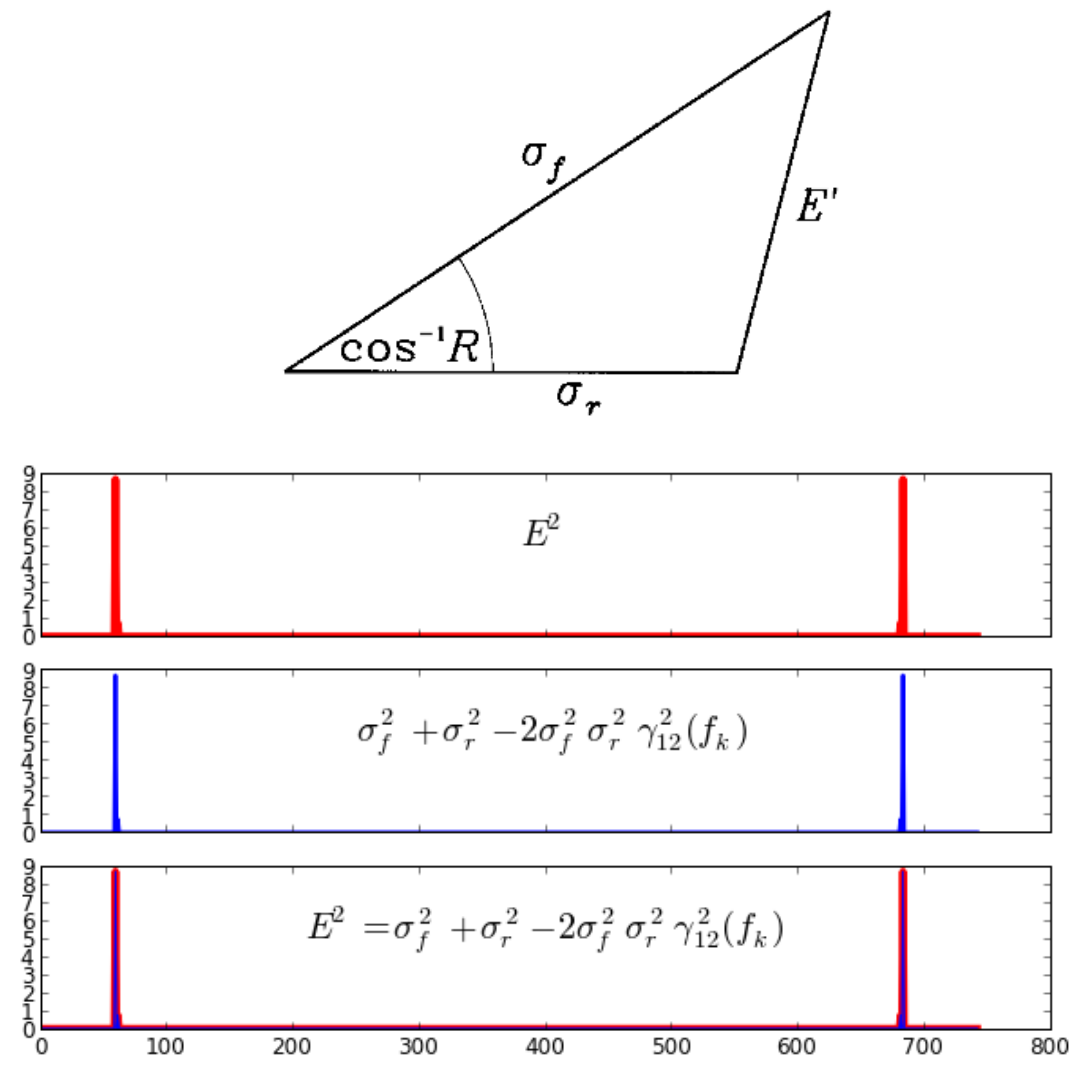

Figure 2: Upper painel: Geometric relationship between correlation coefficient $(R)$, the standard deviations of the test $\left(\sigma_{-} f\right)$ and the reference $\left(\sigma_{-} r\right)$ fields, and the centered root-mean-square difference $\left(E^{\wedge^{\prime}}\right)$ in a TD (Taylor, 2001). Lower painel: artificial series demonstrating the validity of this relationship, root-mean-square difference (in red) equals to second term of the equation (in blue). 
Geosci. Model Dev. Discuss., https://doi.org/10.5194/gmd-2018-5

Manuscript under review for journal Geosci. Model Dev.

Discussion started: 14 March 2018

(c) Author(s) 2018. CC BY 4.0 License.
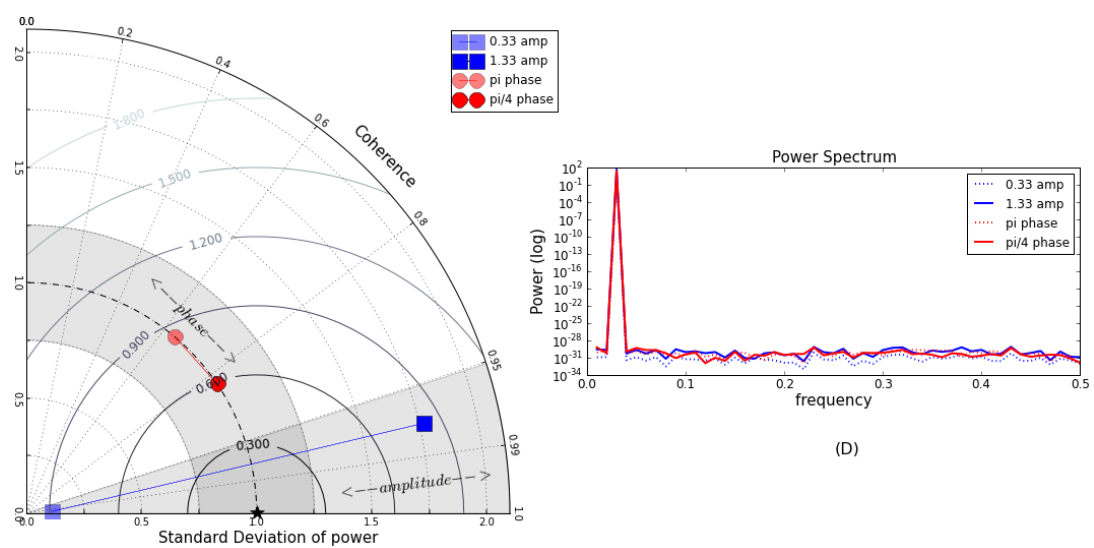

(D)

Figure 3: Spectral Taylor Diagram for displaying patterns in frequency domain shown in (C). The relationship between three statistical quantities: coherence, standard deviation of power, and centered RMS difference are shown. The reference point is marked with a black star, plotted along the abscissa, and all the tests are normalized by the reference standard deviation of power. Artificial series created for test changes in: (A) amplitude and (B) phase. The frequency is fixed for all time series, where obs is the reference, amplitude is changing from 0.33 to 1.33 , and the phase is changing from $180^{\circ}$ to $45^{\circ}$. The standard deviations are proportional to radial distances, the azimuthal position gives the coherence while the concentric labeled lines indicate the centered RMS difference. The Spectral Taylor Diagram better expresses both the changes in amplitude and phase not captured by the power spectrum analysis, shown in (D). 
Geosci. Model Dev. Discuss., https://doi.org/10.5194/gmd-2018-5 Manuscript under review for journal Geosci. Model Dev.

Discussion started: 14 March 2018

(c) Author(s) 2018. CC BY 4.0 License.

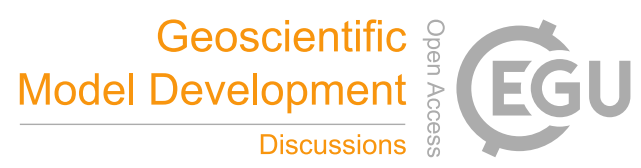

(c) (i)

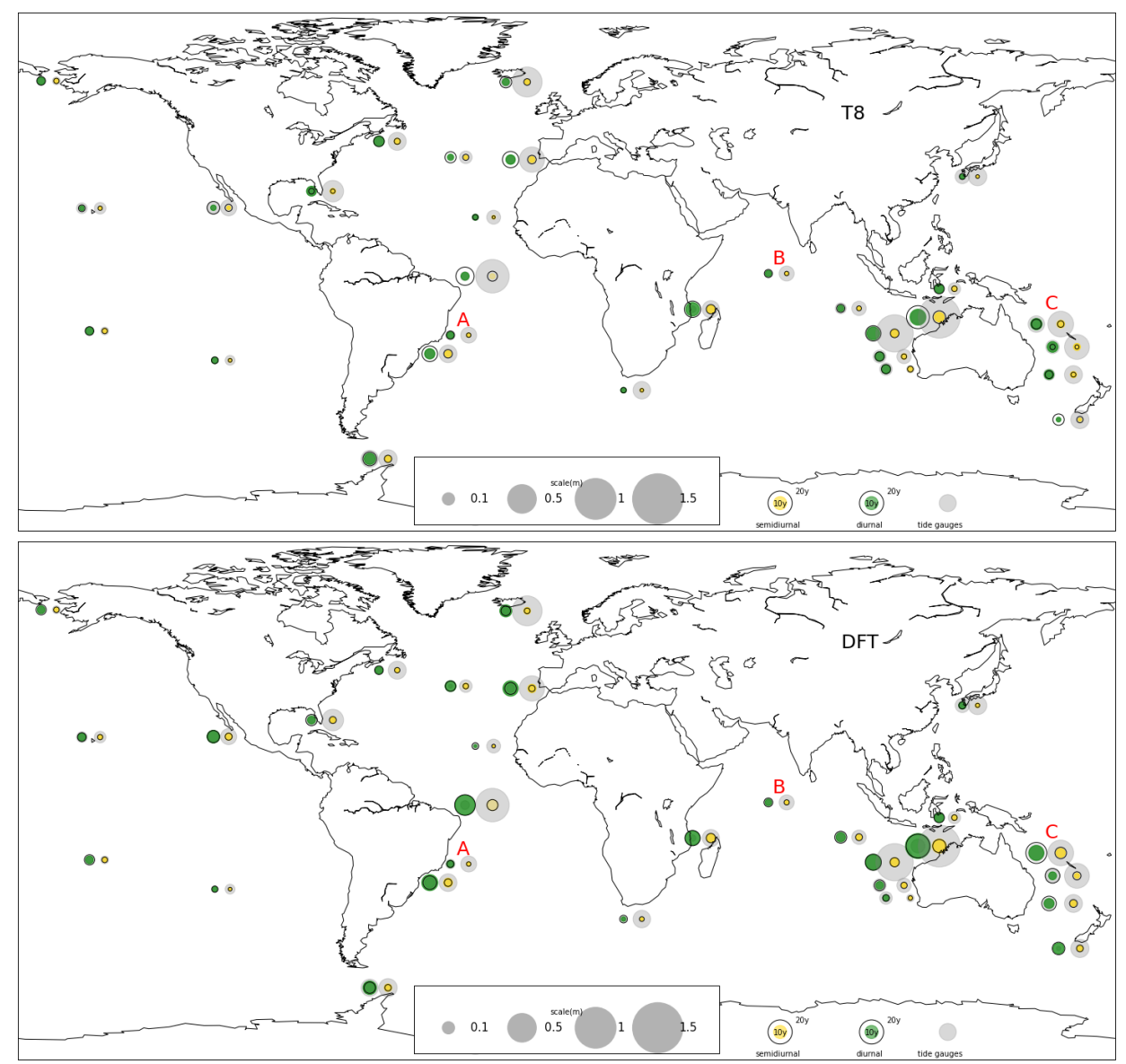

Figure 4: Amplitudes of semidiurnal (yellow) and diurnal (green) averaged tidal constituents estimated after 10th and 20th year of simulation for T8 (top panel) and DFT (lower panel) 
Geosci. Model Dev. Discuss., https://doi.org/10.5194/gmd-2018-5 Manuscript under review for journal Geosci. Model Dev.

Discussion started: 14 March 2018

(c) Author(s) 2018. CC BY 4.0 License.

\section{(c) (1)}
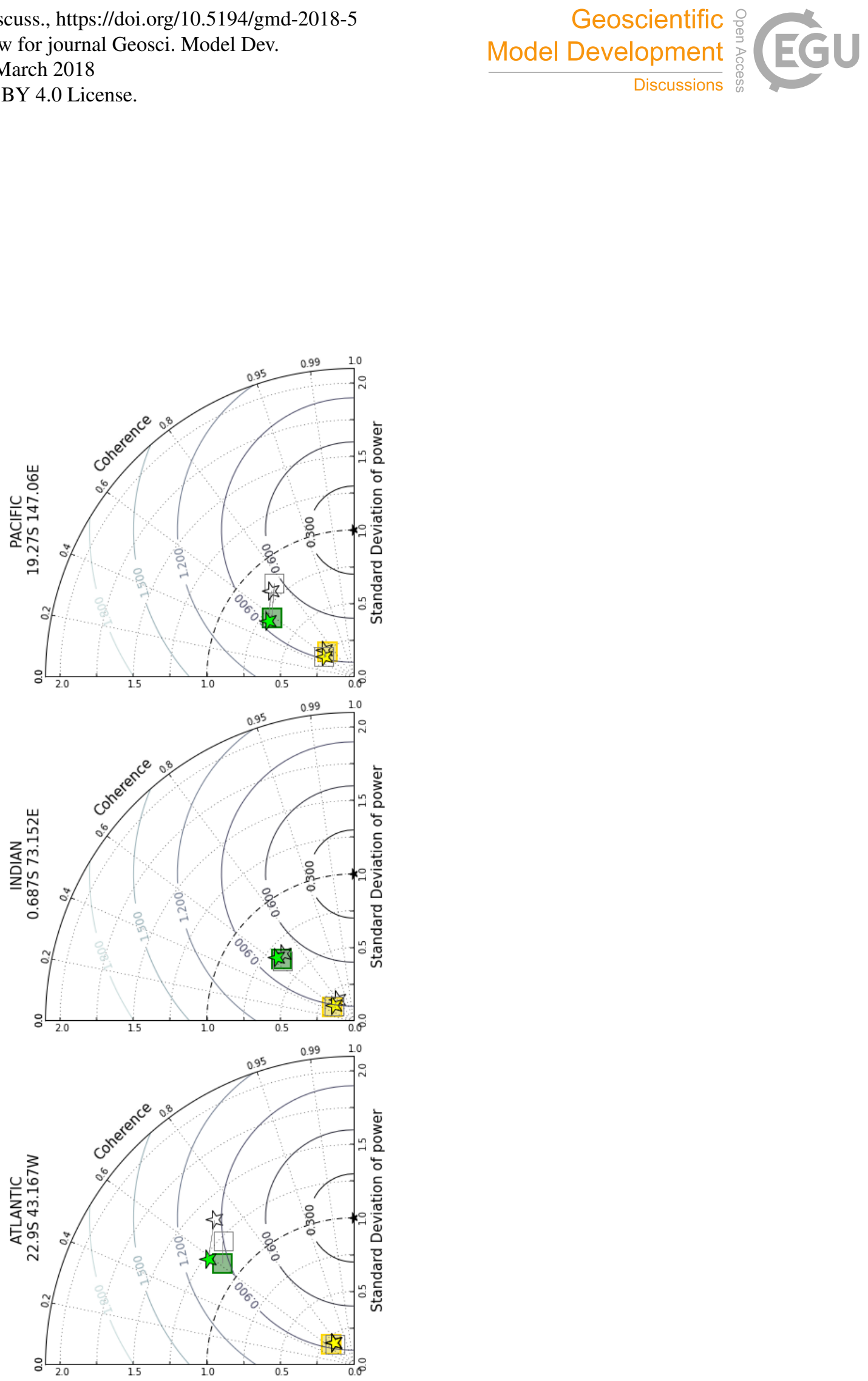
Geosci. Model Dev. Discuss., https://doi.org/10.5194/gmd-2018-5

Manuscript under review for journal Geosci. Model Dev.

Discussion started: 14 March 2018

(c) Author(s) 2018. CC BY 4.0 License.

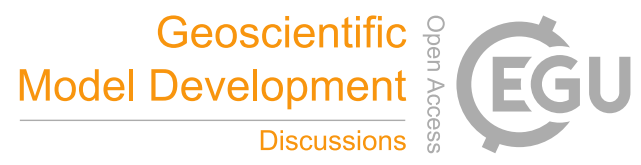

(c) (i)

442 Figure 5: STDs comparing sea-level from T8 and DFT with tidal gauge observations during

443 DJF for an example in the A) Atlantic Ocean (Ilha Fiscal); B) Indian Ocean (Gan); and C)

444 Pacific Ocean (Townsville) - showing the semidiurnal (yellow) and diurnal (green) averaged

445 constituents for DFT (squares) and T8 (stars) at the end of the 10th (filled markers) and 20th

446 (unfilled markers) year of each simulation. The 10th year is connected with 20th year of

447 simulation by a line showing the evolution of the skill of the model's in relation of tide gauge

448 data. The standard deviations of power have been normalized by the observed standard

449 deviation of power. The reference (black star) is also divided into two time periods: 10 years

450 and 20 years after initial condition of 01/01/1992. 
Geosci. Model Dev. Discuss., https://doi.org/10.5194/gmd-2018-5 Manuscript under review for journal Geosci. Model Dev.

Discussion started: 14 March 2018

(c) Author(s) 2018. CC BY 4.0 License.

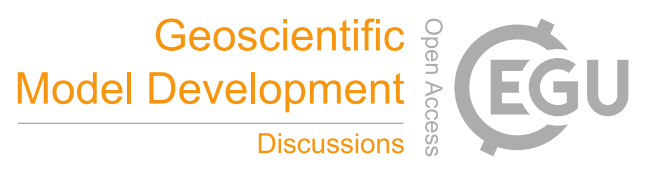

(c) (1)
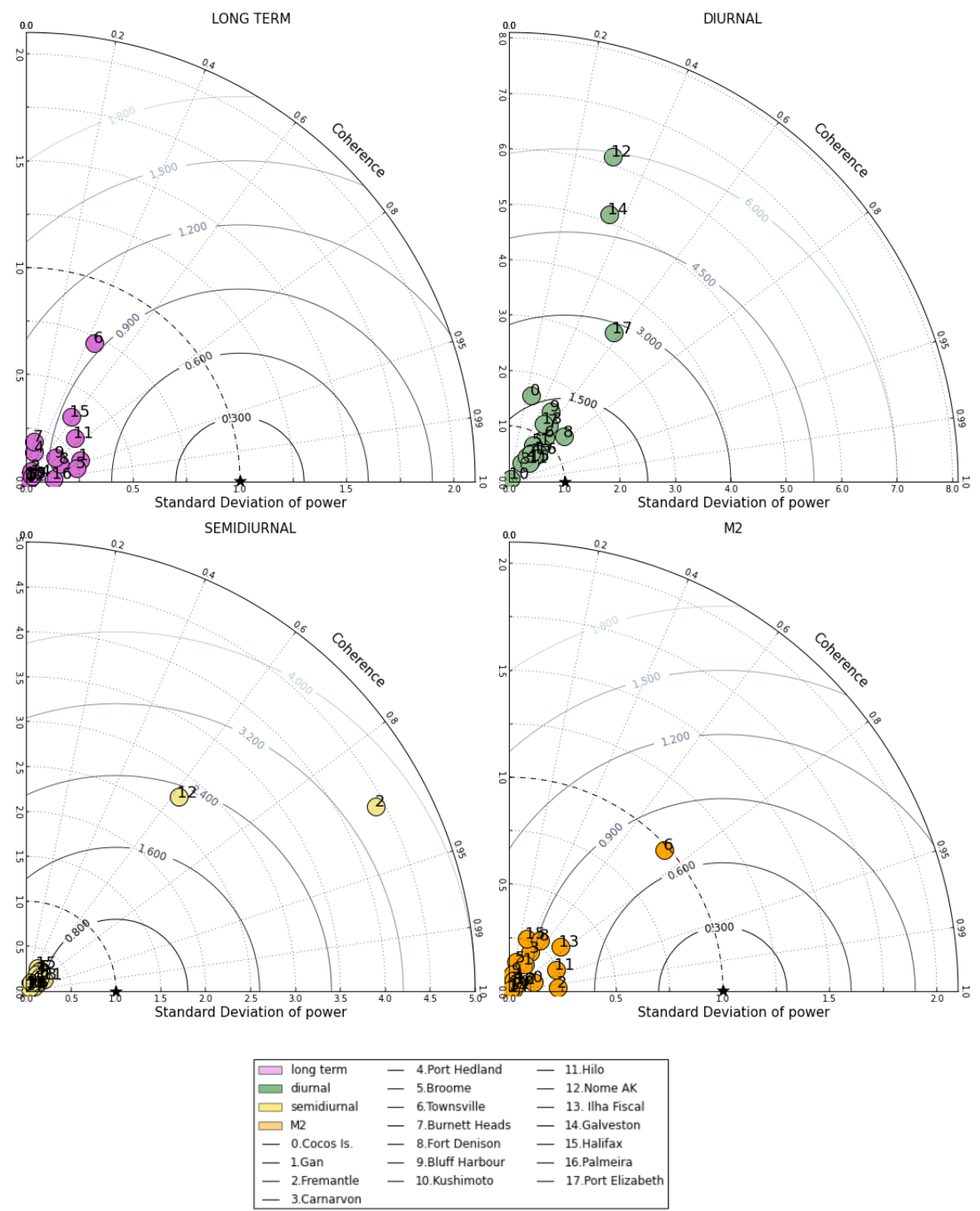

Figure 6 - STDs overall tide gauges stations with significant data (17) separated by frequencies. Upper left: long-term band; Upper right: diurnal band; Lower left: semidiurnal band; and Lower right: M2 frequency. The model does a better job close to Townsville tide 
Geosci. Model Dev. Discuss., https://doi.org/10.5194/gmd-2018-5 Manuscript under review for journal Geosci. Model Dev.

Discussion started: 14 March 2018

(c) Author(s) 2018. CC BY 4.0 License.

\section{(c) (1)}
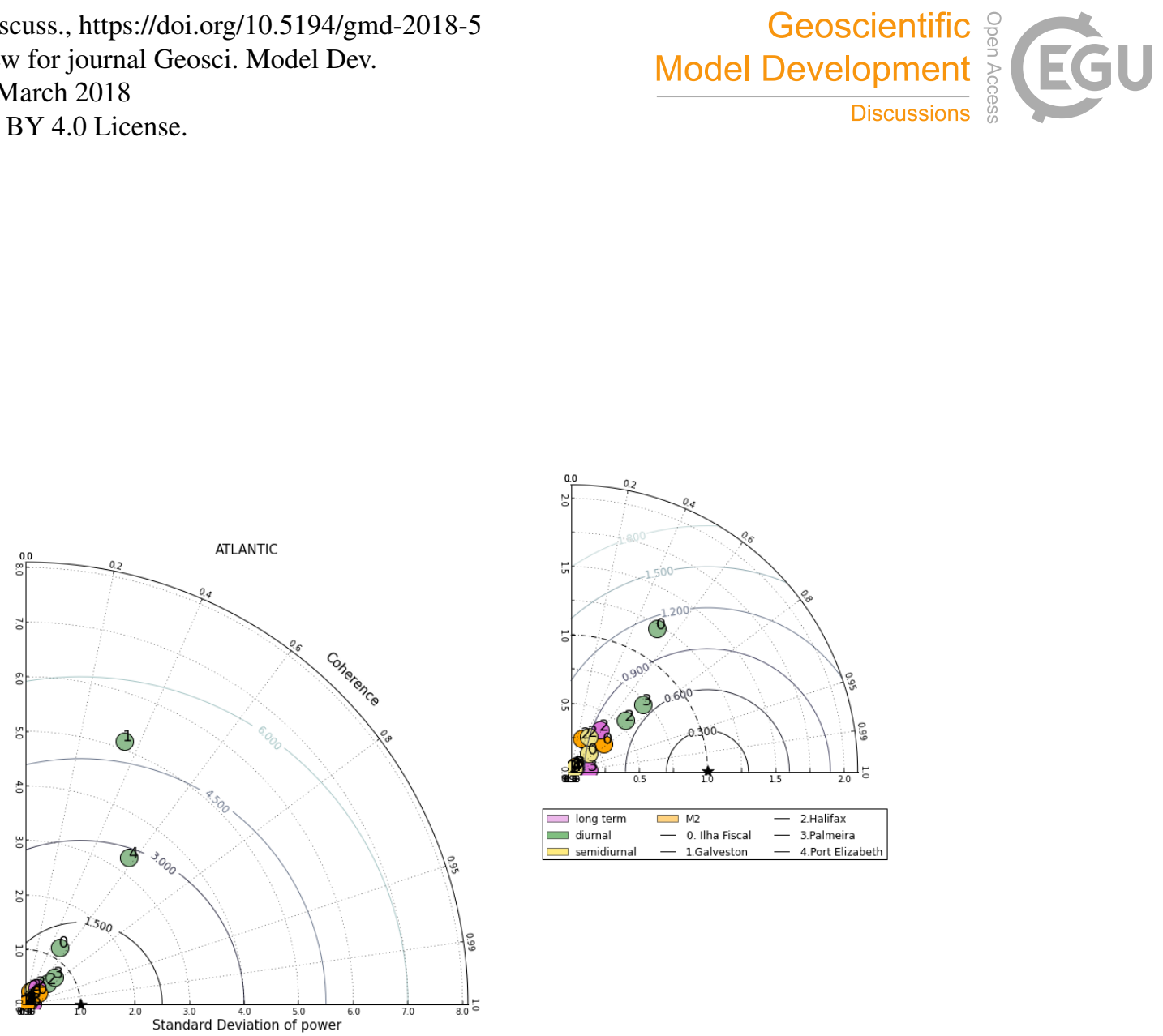

455

Figure 7. STD overall tide gauges stations with significant data (5) in Atlantic Ocean. 
Geosci. Model Dev. Discuss., https://doi.org/10.5194/gmd-2018-5 Manuscript under review for journal Geosci. Model Dev.

Discussion started: 14 March 2018

(c) Author(s) 2018. CC BY 4.0 License.

(c) (1)

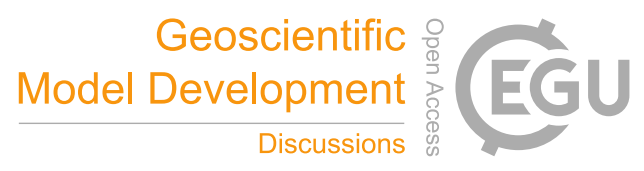

Discussions
456

APPENDIX A

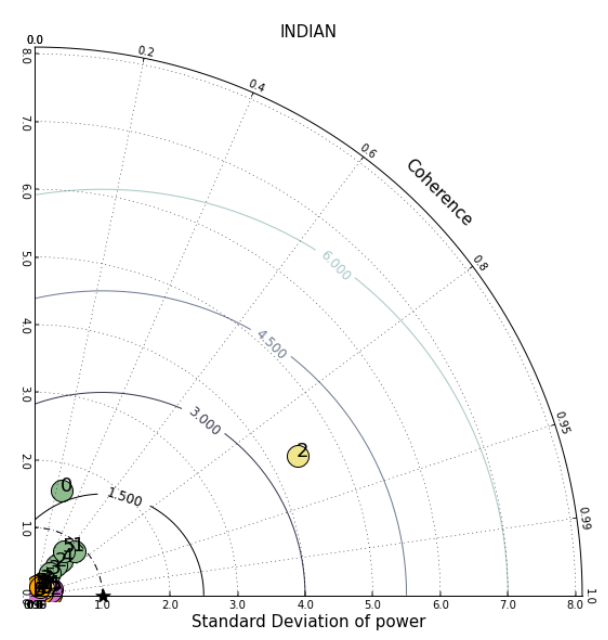

457

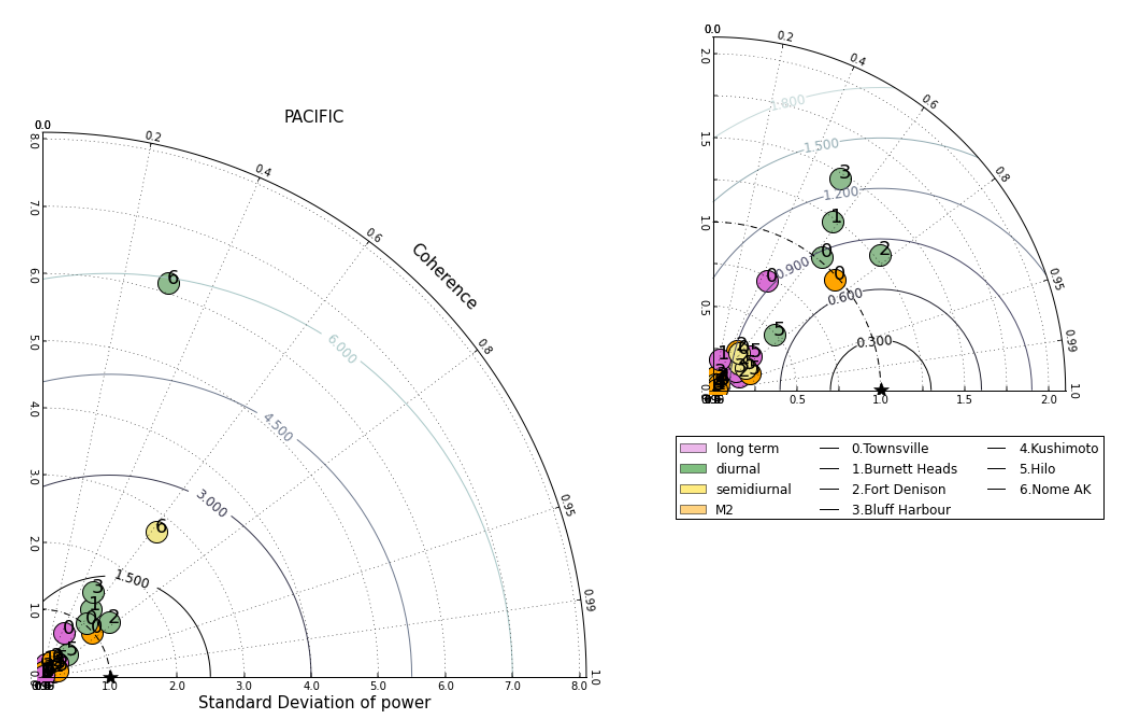

Figure A1. STD overall tide gauges stations with significant data (6) in Indian Ocean.

Figure A2. STD overall tide gauges stations with significant data (5) in Pacific Ocean. 